\title{
The Analysis Of Factors Influencing The Contractor Bid / No Bid Decision Making And The Success Of Tender Bids In Procurement Of Services Construction At PT Inalum (Persero)
}

\author{
Syaifuddin A. Harahap \\ Master of Management , Faculty of Economics and Business, \\ Unversity of North Sumatra \\ Indonesia \\ syaifuddinarafat1975@gmail.com
}

\begin{abstract}
The reliable infrastructures support the success of the company operation dan such achievement would be gained if planning, monitoring and maintaining of the infrastrucutures executed correctly and timely. One method in getting the reliable infrastructures by means of outsource to another party (contractor). This outsource shall be carried oTut in effective and efficient manner, both gained values and expenditured costs point of view. To achieve such goal, it is deemed necessary to make an effective tender of procurement, it means that the tender will bring the company getting a favorable value and the effectiveness can be traced through how many contractors participated and quoted the tender bids as response the quotations offered by the company.
\end{abstract}

Keyword-effective tender, dominant factors influencing bid decision making and success, dominant factors influencing no bid decision making

\section{INTRODUCTION}

The achievement for getting success of the company's operations shall be supported by reliable facilities and infrastructures of equipment and factory infrastructure. Maintenance for establishing facilities and infrastructures such as plant equipment and infrastructure, carried out by the existing human resources of the company itself, as well as due to the company's limited of expertise and supporting equipment or considering to the effectiveness and efficiency, the company will maintain and / or establish such facilities and infrastructure by transferring (outsource) the work to other parties and in this case the party receiving the work is called contractor.

Transfering (outsource) of this work shall impact the expenses compensation which incurred by company to contractor. Another implication that informations and provisions both technical and commercial have to be delivered, interpreted and agreed, so between the company as owner and contractor as executor have no ambiguities and the contractor has to realize the desire of the company. Because of the level importance of the contractor's role to fulfill the company's requirement for a construction service project in mechanical, electrical and civil, so this research will be focused on factors that the contractor make decision to bid / not to bid and the success of tender bids in procurement of services construction at PT Inalum (Persero). The research, taking place at PT Inalum (Persero) in Kuala Tanjung Batu Bara Regency North Sumatera, carried out due to there is a phenomenon in the last 5 years tendency of contractor participation for services construction tender tends to decrease.

Therefore, the purpose of this study is to uncover and analyze 22 factors that have a significant and positive impact on the contractor's decision to bid / not to bid and success of tender bids of services procurement at PT Inalum (Persero) and to find out the most factors dominant through logistic regression analysis.

\section{LITERATURE REVIEW}

\section{A. Previous Research Results}

Previous research is a literature review from the last studies. Researcher has examined and has made synthesis from the related previous study.

Here is some researches related to factor influencing contractor bid / no bid decision making:

1. Research had been done by [1] under the title of research Factors Influencing The Bid / No Bid Decision Making and the Success of Contract Bids in the Telecommunication Industry. The purpose of this study is to provide a list of variables that allow decision makers in the bidding process to collaborate subjective assessments of data based on past events. The research method used is Test-t independent sample data, Correlation Coefficient, Factor Analysis, Logistic Regression Analysis. The results concluded that significantly with a significant level of $5 \%$ of the complete model of logistic regression formed, there are four variables that influence the success of the quote, such as the possibility of future business, competition, availability of financial resources, and the suitability of the projects offered. 
2. Research had been done by [2] with a research title A Frame Work for Contractors to Reach Strategically Correct Bid/no Bid and Mark-up Size Decisions. The goal to be achieved is to identify factors related to the final decision which made structuring in a hierarchy. The research method applied is Data Weight Approach and Factor Analysis. The results of the study conclude that there is a significant difference in the importance of establishing the same key factors for two separate decision-making processes. Factors related to "strategic considerations" have a significant pattern in both decision processes. It is also known that contractor and project factors are strategically considered factors.

3. Research had been done by [3] with title of research Bid/no Bid Decision Modelling for Construction Projects. The purpose of this research is to contribute to the knowledge related to the project evaluation process and the research agenda related to the company's project management in the construction industry. The research method used is parametric method, utility theory, neural network, fuzzy neural network fuzzy logic, regression analysis. The results of this study show that there are ninety-four potential factors divided into ten groups. The ten groups, consist of: project characteristics, business benefits, client characteristics, contracts, financial projects, firm characteristics, previous company experience, supply situation, economic situation, and competition.

\section{B. Related Factors of Decision Making Bid / not to bid}

Lemberg focuses on the determination of which factors influence the successful supply of telecommunication solutions manufacturing systems and introduces on 18 different factors that have been found in previous studies that influence the decision to bid or not to bid and divide the factors into 4 groups such as (1) Contractor, (2) Project, (3) Market, (4) Company [1]. Based on 18 factors are the likely factors of future business activity with the company, the suitability of the proposed project to the specifications requested by the company, market competition and the availability of financial resources are important factors that influence the contractor to bid / not to bid the bidding and success of the quotation.

This paper refers to the studies of $[1,2,4]$ and divides the factors into four groups to differentiate between the factors that are important in making the decision to bid / not to bid. Further, [4,5] grouped differently between factors into different objectives on the decision-making model.

A comparison of 13 different studies has been done. Each of the studies is discussed about the factors that influence the decision to bid / not to bid. The grouping of factors in this research are Contractor, Project, Market, and related to Company / owner. Each group contains factors that relate to the Contractor, Project, Market, and Company / owner.

In previous studies have been explored in different industries, such as the construction industry and electrical and mechanical industries, the factors that emerged in the majority of previous studies can be selected and applied to the procurement activities of services construction at PT Inalum (Persero) located in Kuala Tanjung, Batu Bara District, North Sumatra, Indonesia. In this thesis study, grouping and related factors refer to the study of [1] which in the study, in addition to sourced from previous studies with the scope of procurement packages that are varied, current, and well-suited to existing work packages at PT Inalum (Persero) where major packages of work are valued for large and complex projects related to the renewal of electrical equipment.

Based on the actual condition of the procurement process of services construction in PT Inalum (Persero), especially for complex and new projects, the time limit of quotation is a process of sending the bid request to the contractor until the deadline of submission of bid from contractor or the duration set by the procurement team of PT Inalum (Persero) is still found that the contractor requested the extension period of the bids or the extension of the time limit of quotation due to the condition then the related factor of the time limit of quotation is included as a factor or variable that becomes the hypothesis that the contractor make decision to bid/ not to bid and the success of tender bids of services procurement at PT Inalum (Persero). The shortest bidding period is included in the company category.

Another factor which is found also from the phenomenon of the process of procurement of services construction in PT Inalum (Persero) is the long project that is a requirement requested by PT Inalum (Persero) to the bidder or contractor to the project completion time. Based on the above discussion, there are 22 factors derived from the previous research and the results of observation and direct confirmation of the invited bidders affecting the contractor make decision to bid/ not to bid and the success of tender bids of services procurement at PT Inalum (Persero).

\section{Conceptual Framework}

This research is based on literature searches / previous research literature and that each of the factors has been identified to influence the decision making of the bidding / non-bidding on services construction at PT Inalum (Persero). Based on the the above, the conceptual framework of this research is as follows: 
Variabel X

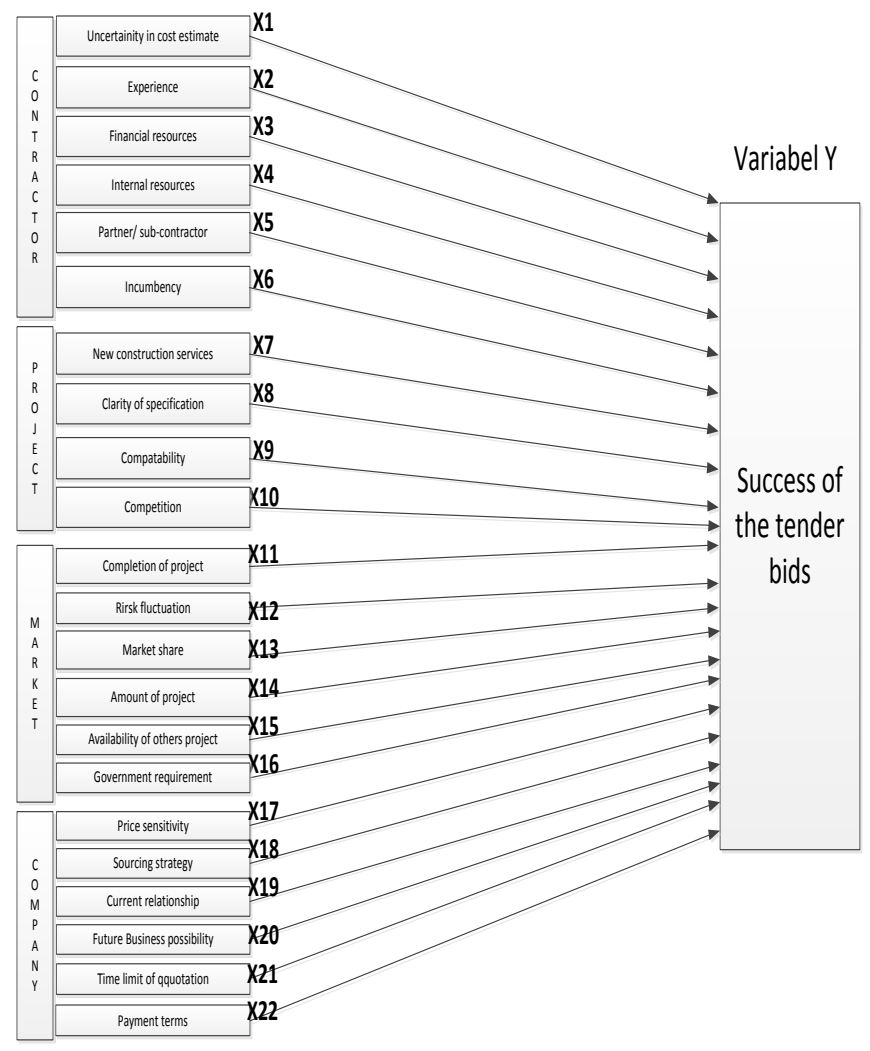

Picture 1. Conceptual Framework

\section{RESEARCH METHODOLOGY}

This kind of research is ex post facto, means that researchers observe the events that have occurred and then trace back to find out the factors that can cause the incident [6].

The approach applied in this research is a survey approach, that is the activity of collecting data as much as possible about the facts that are supporters of research with a view to know the status, symptoms, find the similarity of status by comparing with the standard that has been selected or determined [5].

Judging by the type of data, this research is classified as quantitative research. Quantitative research according to [7], is a scientific approach to decision making, then departing from processed and manipulated data into valuable information for the scientific community. The processing and manipulation of raw data into useful information is what is at the center of quantitative analysis.

\section{A. Population and Sample}

Population is a generalization region consisting of objects / subjects that have certain qualities and characteristics set by the researcher to be studied and then drawn conclusions [8]. Population in this research is all contractor of service procurement of PT Inalum (Persero) Kuala Tanjung Regency with 130 peoples.

Sample is part of the population to be studied and which is considered to be able to describe the population, to determine the required sample with population size known to amount to 130 peoples, the researchers used the Slovin formula as follows:

$$
\mathrm{n}=\frac{N}{1+N e^{2}}
$$

Note :

$\mathrm{n}=$ Sample size

$\mathrm{N}=$ Population size

$\mathrm{e}=$ Error level $5 \%$ (percent of inaccuracy ease due to sampling error)

By using the above formula, total samples or respondents are 100 people.

Slovin formula can be used because the amount of population to be sampled is not large and the population of the research object is known with certainty [9].

Sampling technique in this study is nonprobability sampling because it does not provide the same opportunity for every member of the population to be selected as sample [6]. In this case, to determine the sample is seen in advance a sample that has a certain level or characteristic.

Then, sampling technique in this research using purposive sampling which is sampling technique with certain consideration.

\section{B. Data Analysis Technique}

Data analysis is an activity after all data from respondents or other data sources collected. Activities in data analysis in the form of grouping data based on variables and data types, tabulating data, presenting data of each variable studied, and perform calculations to answer the formulation of the problem and perform calculations to test the hypothesis that has been proposed [10].

- Pearson Correlation Analysis. The Pearson correlation analysis formula is performed by calculating the correlation coefficient. The sample correlation coefficient is generally denoted by $r$. The correlation coefficient is a value expressing the closeness of the relationship between two variables [11]. In many cases, the relationship between variables can occur from two or more variables. The value of the correlation coefficient ranges between -1 and 1 . The value of $r$ getting closer to 1 indicates the stronger the relationship between the two measured factors, whereas the value of $r$ approaching -1 indicates the lower the relation of the two measured factors. 
- Two-Sample Test. In logistic regression, the t-test is used to test the significance of each population regression coefficient. The significance of population regression coefficients was tested based on the sample regression coefficients. The following formulation of the hypothesis to test the significance of regression coefficients individually:

$\mathrm{H} 0: \beta_{i}=0$ (Uncertainty in cost estimate, Experience, Financial resources, Internal resources, Partner / subcontractor, Incumbency, New construction services, Clarity of specifications, Compatability, Competition, Completion of Project, Risk fluctuation, Market share, Amount of project, Availability of others project, Government requirements, Price sensitivity, Sourcing strategy, Current relationships, Future business possibility, Time limit of quotation and Payment terms have a statistically insignificant effect on the success of the tender bids on PT Indonesia Asahan Aluminum ( Persero) Kuala Tanjung Batu Bara Regency).

H1: $\beta_{i} \neq 0$ (Uncertainty in cost estimate, Experience, Financial resources, Internal resources, Partner / subcontractor, Incumbency, New construction services, Clarity of specifications, Compatability, Competition, Completion of Project, Risk fluctuation, Market share, Amount of project, Availability of others project, Government requirements, Price sensitivity, Sourcing strategy, Current relationships, Future business possibility, Time limit of quotation and Payment terms have a statistically significant effect on the success of the tender bids on PT Indonesia Asahan Aluminum ( Persero) Kuala Tanjung Batu Bara Regency).

For decision making on the hypothesis, it can be done by comparing the statistical value of the t-test to the critical value based on the table of the $t$ distribution. Before calculating the $t_{\text {table }}$ value, first calculate the degree of freedom.

The formula for calculating the Degree of Freedom (df):

$$
\text { Degree of freedom }(\mathrm{df})=\mathrm{n}-\mathrm{k}
$$

With :

$n=$ number of elements in the sample

$k=$ number of variables

Next will be tested significance by comparing the level of significance (alpha) $=5 \%$ and $t_{\text {table }}$ with $t_{\text {calculate }}$ obtained by the test criteria used are:

Accept $\mathrm{H}_{0}$ if $\mathrm{t}_{\text {calculate }}<\mathrm{t}_{\text {table }}$

Reject $\mathrm{H}_{0}$ (Accept Ha) if $\mathrm{t}_{\text {calculate }} \geq \mathrm{t}_{\text {table }}$

Decision-making on the hypothesis can also be done using the probability (p-value / Sig. (2-tailed)) approach of the t-Test. The probability value of t test is compared with the level of significance used. In accordance with the criteria that have been done above, then used level of significance (alpha) $=5 \%$. Decisionmaking rules for hypotheses based on probability value approach:

Accept H0 if the probability value is the level of significance

Reject H0 (Accept Ha) if the probability value is a level of significance:

- Factor Analysis. Factor analysis is a method that can reduce a set of original variables into several new variables, called factors or dimensions. Factor analysis attempts to produce a factor with a minimum number of possible factors, which can explain the maximum number of variance in the correlation matrix or matrix $\mathrm{R}$ (the whole variable) [12]. In factor analysis, large variables are grouped into a number of factors that have similar properties and characteristics, making processing easier. Grouping is done by measuring the correlation of a set of variables and subsequently placing high correlated variables in one factor, and other variables having a relatively lower correlation placed on the other. The procedures in performing this analysis are variable selection, factor formation, interpreting the results of the analysis, and validating the results of the factoring.

- Logistic Regression. In linear regression, either simple or multiple, non-free variables are metrics (intervals or ratios), whereas in logistic regression, non-free variables are non-metric (having categories). In linear regression, independent variables are metric (interval or ratio), whereas in logistic regression, independent variables can be metric or non-metric or a combination of the two. Logistic regression can be described as an estimate of the relationship between non-metric (binary) non-free variables and a collection of nonmetric and non-metric independent variables, of which the general form [13]:

$$
Y_{1} \quad=X_{1}+X_{2}+X_{3}+\cdots+X_{n}
$$

$$
\text { (non - metrik biner) (non-metrik and metrik) }
$$

Logistic regression analysis used in this research functioned to find out the most dominant factors over 22 factors, with the dependent variable and independent variable are both non-metric (having categories). The dependent variable relates to the decision of the construction service procurement contractor to bid / not to bid and the independent variables relating to the successful or unsuccessful bidding of PT Inalum (Persero) Kuala Tanjung Kabupaten Batubara. Thus, multiple binary logistic regression equations for 22 factors have the following form:

$\ln \left(\frac{P(y=1)}{1-P(y=1)}\right)=\alpha+\beta_{1} x_{1}+\beta_{2} x_{2}+\cdots+\beta_{k} x_{k^{3}}$

Because in this study using 22 independent variables, then the value of $\mathrm{k}$ until 22. 
Thus, multiple binary logistic regression equations can be written:

$\ln \left(\frac{P(y=1)}{1-P(y=1)}\right)=\alpha+\beta_{1} x_{1}+\beta_{2} x_{2}+\beta_{a} x_{a}+\beta_{4} x_{4}+\beta_{5} x_{5}+\beta_{6} x_{6}+\beta_{7} x_{7}+$ $\beta_{8} z_{8}+\beta_{9} x_{9}+\beta_{10} x_{10}+\beta_{11} x_{11}+\beta_{12} x_{12}+\beta_{12} x_{12}+\beta_{14} x_{14}+\beta_{15} x_{15}+\beta_{16} x_{16}+\beta_{17} x_{17}+\beta_{18} x_{18}+\beta_{19} x_{19}+\beta_{20} x_{20}$ $+\beta_{21} x_{21}+\beta_{22} x_{22}$

Keterangan :

$Y=$ Success of tender bids

$a=$ Constanta

$\beta_{1}, \beta_{2}, \beta_{3, \ldots x}, \beta_{22}=$ Coefficient of variable regression $x_{1}, x_{2}, \ldots, x_{22}$

$x_{1}=$ Uncertainty in cost estimate

$x_{2}=$ Experience

$x_{3}=$ Financial resources

$x_{4}=$ Internal resources

$x_{5}=$ Partner / sub-contractor

$x_{6}=$ Incumbency

$x_{7}=$ New construction services

$x_{8}=$ Clarity of specifications

$x_{9}=$ Compatability

$x_{10}=$ Competition

$x_{11}=$ Completion of project

$x_{12}=$ Risk Fluctuation

$x_{13}=$ Market share

$x_{14}=$ Amount of Project

$x_{15}=$ Availability of others project

$x_{16}=$ Government requirements

$x_{17}=$ Price sensitivity

$x_{18}=$ Sourcing Strategy

$x_{19}=$ Current relationships

$x_{20}=$ Future business Possibility

$x_{21}=$ Time limit of quotation

$x_{22}=$ Payment teerms

\section{RESULTS AND DISCUSSION}

\section{Correlation coefficient}

The value of the correlation coefficient ranges between -1 and 1 . The value of $r$ getting closer to 1 indicates the stronger the relationship between the two measured factors, while the value of $r$ approaching -1 indicates the lower the relation of the two measured factors

Table I below shows the assessment information of the two groups of respondents by only looking at the correlation coefficient value between the two highest variables
TABLE I. COEFFICIENT VALUE OF CORRELATION AND PROBABILITY

\begin{tabular}{|c|c|c|}
\hline Variable & $\begin{array}{c}\text { Coefficient Value of } \\
\text { Correlation }\end{array}$ & $\begin{array}{l}\text { Probability / } \\
\text { Sig. (2-Tailed) }\end{array}$ \\
\hline $\mathrm{X} 1 \rightarrow \mathrm{X} 18$ & 0,927 & 0,000 \\
\hline $\mathrm{X} 2 \rightarrow \mathrm{X} 4$ & 0,794 & 0,000 \\
\hline $\mathrm{X} 3 \rightarrow \mathrm{X} 7$ & 1,000 & 0,000 \\
\hline $\mathrm{X} 4 \rightarrow \mathrm{X} 8$ & 0,879 & 0,000 \\
\hline $\mathrm{X} 5 \rightarrow \mathrm{X} 20$ & 0,910 & 0,000 \\
\hline $\mathrm{X} 6 \rightarrow \mathrm{X} 9$ & 0,966 & 0,000 \\
\hline $\mathrm{X} 7 \rightarrow \mathrm{X} 3$ & 1,000 & 0,000 \\
\hline $\mathrm{X} 8 \rightarrow \mathrm{X} 15$ & 0,927 & 0,000 \\
\hline $\mathrm{X} 9 \rightarrow \mathrm{X} 6$ & 0,966 & 0,000 \\
\hline $\mathrm{X} 10 \rightarrow \mathrm{X} 1$ & 0,879 & 0,000 \\
\hline $\mathrm{X} 11 \rightarrow \mathrm{X} 13$ & 0,966 & 0,000 \\
\hline $\mathrm{X} 12 \rightarrow \mathrm{X} 14$ & 1,000 & 0,000 \\
\hline $\mathrm{X} 13 \rightarrow \mathrm{X} 11$ & 0,966 & 0,000 \\
\hline $\mathrm{X} 14 \rightarrow \mathrm{X} 12$ & 1,000 & 0,000 \\
\hline $\mathrm{X} 15 \rightarrow \mathrm{X} 8$ & 0,927 & 0,000 \\
\hline $\mathrm{X} 16 \rightarrow \mathrm{X} 17$ & 0,910 & 0,000 \\
\hline $\mathrm{X} 17 \rightarrow \mathrm{X} 16$ & 0,910 & 0,000 \\
\hline $\mathrm{X} 18 \rightarrow \mathrm{X} 1$ & 0,927 & 0,000 \\
\hline $\mathrm{X} 19 \rightarrow \mathrm{X} 22$ & 1,000 & 0,000 \\
\hline $\mathrm{X} 20 \rightarrow \mathrm{X} 5$ & 0,910 & 0,000 \\
\hline $\mathrm{X} 21 \rightarrow \mathrm{X} 10$ & 0,794 & 0,000 \\
\hline $\mathrm{X} 22 \rightarrow \mathrm{X} 19$ & 1,000 & 0,000 \\
\hline
\end{tabular}

Based on Table I above, it can be seen that there are 3 highest correlation coefficient value, that is value 1,000 , 0,966 , and 0,927 . This means that the relationship between the two factors measured has a value of 0.966 and 0.927 can be said very closely, while for the relationship between two factors measured has a value of 1,000 can be said to have a perfect relationship. Then, when viewed from the probability value, overall has the same probability / Sig (2-tailed) value of 0,000 . That means, all factors measured are significant $\alpha=0,05$ because they are smaller than the level of significance. Based on table I above also obtained information in the form of several variables with high correlation value and significant relationship between variables $\mathrm{X} 3$ with $\mathrm{X} 7, \mathrm{X} 7$ with X3, X12 with X14, X14 with X6, X11 with X13, X13 with X11, X1 with X18, X8 with X15, X15 with X8, and X18 with $\mathrm{X} 1$.

\section{T-Test of Two Samples}

The two-sample test is an analysis involving two measurements on the same subject to a particular influence / treatment. Therefore, Table II below shows the assessment results of two assessment groups from the respondents 
TABLE II. MEAN OF RESPONDENT RESPONSE FOR BID DECISION MAKING AND SUCCESS AND FOR NO BID DECISION MAKING, DIFFERENCE OF MEAN, $\mathrm{T}_{\text {CALCUlate }}$ AND SIGNIFICANCY OF T-TEST 2 SAMPLE

\begin{tabular}{|c|c|c|c|c|c|}
\hline Variable & $\begin{array}{l}\text { Mean for bid } \\
\text { decision } \\
\text { making and } \\
\text { success }\end{array}$ & $\begin{array}{c}\text { Mean for no } \\
\text { bid decision } \\
\text { making }\end{array}$ & $\begin{array}{c}\text { Difference } \\
\text { of mean }\end{array}$ & $\mathrm{T}_{\text {calculate }}$ & $\begin{array}{l}\text { Sig. (2- } \\
\text { tailed) }\end{array}$ \\
\hline $\begin{array}{l}\text { Uncertainity in cost } \\
\text { estimate (X1) }\end{array}$ & 3,51 & 4,27 & $-0,760$ & $-15,359$ & 0,000 \\
\hline Experiance (X2) & 4,65 & 3,29 & 1,360 & 28,191 & 0,000 \\
\hline $\begin{array}{l}\text { Financial resources } \\
\text { (X3) }\end{array}$ & 3,65 & 3,65 & 0,000 & - & - \\
\hline $\begin{array}{l}\text { Internal resources } \\
\text { (X4) }\end{array}$ & 4,29 & 3,26 & 1,030 & 18,433 & 0,000 \\
\hline $\begin{array}{l}\text { Partner/ sub- } \\
\text { contractor (X5) }\end{array}$ & 3,88 & 3,55 & 0,330 & 5,050 & 0,000 \\
\hline Incumbency (X6) & 3,77 & 3,65 & 0,120 & 3,674 & 0,000 \\
\hline $\begin{array}{l}\text { New construction } \\
\text { services }(X 7)\end{array}$ & 3,65 & 3,65 & 0,000 & - & - \\
\hline $\begin{array}{c}\text { Clarity of } \\
\text { specification (X8) }\end{array}$ & 4,27 & 3,51 & 0,760 & 15,359 & 0,000 \\
\hline Compatability (X9) & 3,73 & 3,65 & 0,080 & 2,934 & 0,004 \\
\hline Competition (X10) & 3,26 & 4,29 & $-1,030$ & $-18,433$ & 0,000 \\
\hline $\begin{array}{l}\text { Completion of } \\
\text { project (X11) }\end{array}$ & 3,65 & 3,73 & $-0,080$ & $-2,934$ & 0,004 \\
\hline $\begin{array}{l}\text { Risk fuktuation } \\
\text { (X12) }\end{array}$ & 3,65 & 3,65 & 0,000 & - & - \\
\hline Market share (X13) & 3,65 & 3,77 & $-0,120$ & $-3,674$ & 0,000 \\
\hline $\begin{array}{l}\text { Amount of project } \\
\text { (X14) }\end{array}$ & 3,65 & 3,65 & 0,000 & - & - \\
\hline $\begin{array}{l}\text { Availability of the } \\
\text { others project(X15) }\end{array}$ & 4,20 & 3,53 & 0,670 & 12,574 & 0,000 \\
\hline $\begin{array}{c}\text { Government } \\
\text { requirement }(\mathrm{X} 16)\end{array}$ & 3,55 & 3,88 & $-0,330$ & $-5,060$ & 0,000 \\
\hline $\begin{array}{l}\text { Price Sensitivity } \\
\text { (X17) }\end{array}$ & 3,59 & 3,81 & $-0,220$ & $-3,921$ & 0,000 \\
\hline $\begin{array}{l}\text { Sourcing strategy } \\
\text { (X18) }\end{array}$ & 3,53 & 4,20 & $-0,670$ & $-12,574$ & 0,000 \\
\hline $\begin{array}{l}\text { Current relationship } \\
\text { (X19) }\end{array}$ & 3,65 & 3,65 & 0,000 & - & - \\
\hline $\begin{array}{l}\text { Future business } \\
\text { possibility (X20) }\end{array}$ & 3,81 & 3,59 & 0,220 & 3,921 & 0,000 \\
\hline $\begin{array}{c}\text { Time limit of } \\
\text { quotation (X21) }\end{array}$ & 3,29 & 4,65 & $-1,360$ & $-28,191$ & 0,000 \\
\hline $\begin{array}{l}\text { Payment terms } \\
\text { (X22) }\end{array}$ & 3,65 & 3,65 & 0,000 & - & - \\
\hline
\end{tabular}

Value $\mathrm{t}_{\text {calculate }}$ for variabel X3, X7, X12, X14, 19, X22 can not be counted due to different value of standard error $=0$, so it is impossible the devide result against nil (0)

From Table II above it is known that there are three variables that have the highest value of $\mathrm{t}_{\text {calculate }}$ and the Sig (2tailed) value which is far below the $5 \%$ significance level, as compared to the results obtained by other variables. The three variables are Experience (X2) with $\mathrm{t}_{\text {calculate }}$ of 28,191 and Sig. $(2$-tailed $)=0,000$, Internal resource $(\mathrm{X} 4)$ with $\mathrm{t}_{\text {calculate }}$ value $=$ 18,433 and Sig. (2-tailed) $=0,000$, Clarity of specification

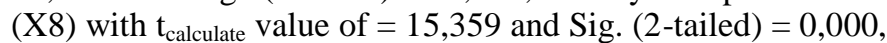
and Availability of the others project (X15) with $t_{\text {calculate value }}$ $=12,574$ and Sig. (2-tailed) =0,000. Then, to know whether the four variables are significant or not, then tested by comparing the $t_{\text {calculate }}$ value with $t_{\text {table }}$ obtained by the test criteria used

are:
The following is the formulation of the hypothesis to test the individual regression coefficient significance for these four variables:

H0: $\beta_{2}, \beta_{4}, \beta_{8}, \beta_{15}=0$ (Experience, Internal resources, Clarity of specifications and Availability of the others project have statistically insignificant effect on the success of the Tender Bids to PT Indonesia Asahan Aluminum (Persero) $\begin{array}{llll}\text { Kuala Tanjung Batubara } & \text { District). }\end{array}$

Ha: $\beta_{2}, \beta_{4}, \beta_{8}, \beta_{15}=0$ (Experience, Internal resources, Clarity of specifications and Availability of the others project have statistically significant effect on the success of the Tender Bids to PT Indonesia Asahan Aluminum (Persero) Kuala Tanjung Batubara District).

Then, note that the Degree of Freedom (df) for $t_{\text {tables }}$ are searched

df $=n-k=100-23=77$

So obtained: $\mathrm{t}_{\text {table }}=(\mathrm{df} ;$ alpha $)=(77,0,05)=1,66$.

Since the values for all four variables are all greater than alpha,

$\beta_{2}=28,191>0,05, \beta_{4}=18,433>0,05, \beta_{8}=15,1359>0,05$, $\beta_{15}=12,574>0,05$

the test criteria used are Reject H0 (Accept Ha).

In other words, the four variables of experience, internal resources, clarity of specifications, and Availability of the others project have a statistically significant influence on the success of tender quotation on PT Indonesia Asahan Aluminum (Persero) Kuala Tanjung Batubara District.

\section{Factor Analysis}

Factor analysis procedure begins with the selection of variables, the formation of factors, until the validation of the results factoring. In this case, the factors will be grouped to see the variables that have the same data pattern. The process of grouping is done by looking at the value of correlation coefficient between variables, ranging from high value to low. The end result of this process, will form a new factor. After going through the process of factor analysis using SPSS software, obtained results formed a group of three new factors shown in the table below.

Accept $\mathrm{H}_{0}$ if $\mathrm{t}_{\text {calculate }}<\mathrm{t}_{\text {table }}$

Reject $\mathrm{H}_{0}$ (Accept $\mathrm{Ha}$ ) if $\mathrm{t}_{\text {calculate }} \geq \mathrm{t}_{\text {table }}$ 
TABLE III. FACTOR GROUPING

\begin{tabular}{lcccc}
\hline & $\begin{array}{c}\text { Component } \\
1\end{array}$ & $\begin{array}{c}\text { Component } \\
2\end{array}$ & $\begin{array}{c}\text { Component } \\
3\end{array}$ & $\begin{array}{l}\text { Cronbach's } \\
\text { alpha }\end{array}$ \\
\hline Financial resources & 0,947 & & & \\
Incumbency & 0,843 & & & \\
New contruction services & 0,946 & & & \\
Compatability & 0,872 & & & \\
Competition & 0,872 & & & \\
Risk fluctuation & 0,946 & & & \\
Market share & 0,843 & & & \\
Amount of project & 0,946 & & & \\
Current relationship & 0,946 & 0,770 & \\
Payment terms & 0,946 & 0,826 & & \\
Experiance & & 0,810 & & \\
Internal resources & 0,937 & & \\
Partner / sub-contractor & 0,940 & & \\
Clarity of specification & 0,766 & & \\
Availability of the others project & & 0,937 \\
Future business possibility & & 0,826 & \\
Uncertainty in cost estimate & & 0,810 & \\
Completion of project & & 0,940 & \\
Government requirements & & & \\
Price sensitivity & & & \\
Sourcing strategy & & & \\
Time limit of quotation & & & \\
\hline
\end{tabular}

\section{Logistic Regression}

Logistic regression analysis used in this study serves to find out the most dominant factors on 22 factors after the formation of 3 new groups for these factors. In this case, the dependent variable and the independent variable are both nonmetric (having categories). The independent variable is related to the decision of the construction service procurement contractor to bid / not to bid and the dependent variable related to the success or failure of tender quotation on PT Inalum (Persero) Kuala Tanjung Batubara District.

Logistic regression analysis used in this study was calculated by adding factors that have been obtained from the analysis of the above factors into independent variables. The indicator used to see the end result of this process is to look at the value of $\operatorname{Exp}(\mathrm{B})$ and the Sig value. A newly formed group of factors that has a high Exp (B) value of all existing values and the Sig value. which is far below the 5\% significance level, is known to be a highly probable variable for significance.

TABLE IV. RESULT OF LOGISTIC REGRESSION ANALYSIS WITH FACTORS ARE PRODUCED USING PCA (PRINCIPAL COMPONENT ANALYSIS) METHOD WITH VARIMAX ROTATION

\begin{tabular}{|l|c|c|c|}
\hline \multicolumn{1}{|c|}{ Step 1 $^{\mathbf{a}}$} & B & Sig. & Exp(B) \\
\hline CONTRACTOR & 0,000 & 1,000 & 1,000 \\
\hline MARKET & 8,888 & $\mathbf{0 , 0 0 0}$ & $\mathbf{7 2 4 4 , 1 5 6}$ \\
\hline COMPANY & $-8,888$ & 0,000 & 0,000 \\
\hline Constant & 0,000 & 1,000 & 1,000 \\
\hline
\end{tabular}

From Table IV it is known that there are three new factor groups that have been obtained from previous factor analysis process, for ease of data processing, made into new free variable with name CONTRACTOR for first group factor, MARKET for second group factor, and COMPANY for third group factor. The process of forming the three independent variables is done by grouping the score value of each factor with regression method.

Then, from Table IV can also be obtained information that there are two independent variables that have significant values below the value of alpha $=0.05$, namely the variable CONTRACTOR and MARKET, so it is known there are two significant independent variables. However, those two variables that have the largest $\operatorname{Exp}(B)$ value are owned by the MARKET variable. Thus, the MARKET free variable is a more highly probable variable to be significant.

Also known that the MARKET free variable is a collection of scores from each regression factor of a set of factors that exist in the second factor group from the previous factor analysis process. Thus, to know which variable has the most significant effect on the MARKET variable, it must be known that the correlation coefficient coefficient has the highest attachment to MARKET. Table $\mathrm{V}$ below shows the three variables that have the highest relationship closeness to the MARKET variable.

TABLE V. VALUE OF COEFFICIENT CORRELATION GROUP OF SECOND FACTORS TO MARKET

\begin{tabular}{|c|c|c|c|c|c|c|c|}
\hline & MARKET & $\mathrm{X} 2$ & $\mathrm{X} 4$ & $\mathrm{X} 5$ & $\mathrm{X} 8$ & $\mathrm{X} 15$ & $\mathrm{X} 20$ \\
\hline MARKET & 1,000 & 0,770 & $\mathbf{0 , 8 2 6}$ & 0,810 & $\mathbf{0 , 9 3 7}$ & $\mathbf{0 , 9 4 0}$ & 0,766 \\
\hline $\mathrm{X} 2$ & & 1,000 & 0,794 & 0,601 & 0,763 & 0,744 & 0,581 \\
\hline $\mathrm{X} 4$ & & & 1,000 & 0,589 & 0,879 & 0,813 & 0,558 \\
\hline $\mathrm{X} 5$ & & & & 1,000 & 0,709 & 0,760 & 0,910 \\
\hline $\mathrm{X} 8$ & & & & & 1,000 & 0,927 & 0,678 \\
\hline $\mathrm{X} 15$ & & & & & & 1,000 & 0,726 \\
\hline $\mathrm{X} 20$ & & & & & & & 1,000 \\
\hline
\end{tabular}

In accordance with the principle of Pearson correlation analysis which is a value that states the closeness of the relationship between two variables [11]. The value of the correlation coefficient ranges between -1 and 1 . The value of $r$ getting closer to 1 indicates the stronger the relationship between the two measured factors. Therefore, from Table $\mathrm{V}$ above it is known that there are three variables that have a high closeness relationship to MARKET, ie Availability of the others project factor (X15), Clarity of specification (X8), and Internal resources (X4) with correlation coefficient values of $0.940,0.937$, and 0.826 , respectively. Thus, these three factors are known as factors that have a significant and positive effect on the bid / non-bid decision and the successful tender quotation of service construction procurement procurement at PT Inalum (Persero). Thus, multiple binary logistic regression equations for the 3 selected factors have the following form:

$\ln \left(\frac{P(y=1)}{1-P(y=1)}\right)=\alpha+\beta_{4} x_{4}+\beta_{8} x_{8}+\beta_{15} x_{15}$ 


\section{CONCLUSION}

Parson correlation analysis, two sample samples, factor analysis, and logistic regression analysis were conducted to find and analyze 22 factors that had a significant and positive influence on the contractor's decision to bid / not to bid and the success of tender quotation on the procurement of construction services at PT Inalum (Persero) and find out the most dominant factors over 22 factors. Thus, based on the results of research that has been done is known that from 3 groups of new factors formed through the process of factor analysis and to be able to perform logistic regression analysis, 3 groups of new factors are converted into 3 new free variables. From the logistic regression analysis process, it is known that there is one independent variable that is the second free variable (MARKET) which has small $p$-value value and Exp (B) biggest. It is known that Availability of the others project factors (X15), Clarity of specifications (X8), and Internal resources (X4) with correlation coefficient values of $0.940,0.937$, and 0.826 , respectively have the highest correlation to the MARKET free variables, so these 3 factors are selected as the most dominant factor. However, the analysis data result also explain respectivley 3 dominant factors influencing the contractor no bid decision making such as Price sensitivity, Time limit of quotation and Completion of project.

\section{References}

[1] Lemberg, Jaakko. 2013. Factors influencing the bid/ no bid decision making and the success of contract bids in the telecommunication industry. Netherlands, University of Twente.

[2] Egemen,M.,\& Mohamed,A.N. 2007. A frame work for contractors to reach strategically correct bid/no bid and mark-up size decisions. Building and Environment, 42(3),1373-1385. doi:http://dx.doi.org/10.1016/j.buildenv.2005.11.016.

[3] Bagies,A., \& Fortune,C. 2006. Bid/no bid decision modelling for construction projects. Paper presented at the Proceedings of the Association of Researchers in Construction Management Annual Conference,4-6 September, Birmingham.

[4] Ahmad,I. 1990. Decision - Support System for Modeling Bid No - Bid Decision Poblem. Journal of Construction Engineering and Management-Asce, 116 (4), 595-608.doi:Doi10.1061/(Asce)07339364(1990)116:4(595).

[5] Arikunto, Suharsimi. 2006. Prosedur Penelitian Suatu Pendekatan Praktik. Jakarta: Rineka Cipta.

[6] Sugiyono, 2001. Metode Penelitian Bisnis. Bandung : Alfabeta.

[7] Kuncoro, Mudrajad. 2007. Metode Riset untuk Bisnis dan Ekonomi. Jakarta : Erlangga.

[8] Sugiyono. 2008. Metode Penelitian Bisnis. Cetakan Keenam. Bandung: Alfabeta.

[9] Sinulingga, Sukaria. 2015. Metode Penelitian. Edisi Ketiga. Medan: USU Press.

[10] Sugiyono, 2012. Memahami Penelitian Kualitatif. Bandung : Alfabeta.

[11] Sudjana. 2000. Metode Statistika. Edisi Keenam. Bandung : Tarsito.

[12] Field, A. 2009. Discovering Statistics Using SPSS, $3^{\text {rd }}$ Edition. London: Sage.

[13] Hair, J. F Jr., R.E. Anderson, B.J. Babin, dan W.C. Black. 2010. Multivariate Data Analysis, $7^{\text {th }}$ Edition. Pearson Prentice Hall. 